\title{
Traditional Music and the World Music Marketplace: a Producer's Experience
}

\author{
Joe Boyd
}

I first heard the teenage Youssou N'Dour singing with the Star Band of Dakar in the late 1970s. From an early age, it was clear that his was one of Africa's most exciting voices. He soon took over the Star Band, changed its name to Les Super Etoiles de Dakar and began touring outside Africa. I saw them in London in the mid-1980s and was impressed, but with reservations. The Youssou I saw was already hedging his bets, diluting the home grown mbalax rhythms with elements of Western pop. His first European releases had slick production values; he co-wrote songs with Peter Gabriel and toured with Sting. Back in Dakar, meanwhile, he put out hastilyrecorded cassettes for local consumption that were far more exciting than the bland concoctions he released on CD.

When he was signed to Virgin Records in the late 1980s, one of their A \& R (Artists and Repertoire) men had an idea that I might be a good producer for him. There ensued a proxy dialogue in which Youssou and I debated some of the key issues concerning cultural expression and appropriation through messages relayed back and forth via the Virgin office. I told the A \& R man that if I were Youssou N'dour's producer, I would urge him to make a record for the growing World Music audience like the cassettes he made for the Senegalese market. I could promise him a better sound, but I wanted as few hi-tech distortions as possible. He had used a jazz keyboard player, for example, on his first Virgin CD; I wanted none of that - just Senegalese musicians.

Youssou N'dour was outraged: he accused me of racism, of wanting to keep him as an exhibit in an anthropological museum. As far as he was concerned, he was going to be an international star and whatever recording techniques Michael Jackson used, he would use as well. I sent him a message saying I was sorry he had been offended by my suggestions, but I was just being practical. The audience that bought Michael Jackson's CDs was not willing to listen to 50 minutes of singing in Wolof, no matter how good. And the audience that is happy with lyrics they do not 
understand is an educated niche group fleeing from modern pop as represented by Michael Jackson. This audience wants virtuosity and a sense of roots and tradition, the spontaneous energy of a live recording session where great musicians interact in real time; what they once found in jazz, rhythm \& blues, folk music or early rock ' $n$ ' roll, in other words. What they do not want is high-tech polished perfection. Although far smaller than the vast pop marketplace, the World Music audience was not fickle: once they knew you, they would keep buying your records and coming to your concerts. I also pointed out that the sort of recording I proposed could be done in two weeks on a five-figure budget. Youssou N'dour was in the habit of taking months and burning through six figures - and, of course, not recouping the production costs. Needless to say, I heard no more from Youssou. I would be lying if I said it gives me no satisfaction to report that Youssou N'Dour's subsequent recording career has been spectacularly unsuccessful. The flood of red ink in his royalty accounts at Virgin, then Sony and now Warner/Nonesuch is far greater than that of any other artist from the developing world. And the biggest successes in World Music during that period have all been recorded without effects or overdubs: Ladysmith Black Mambazo, Le Mystere de Voix Bulgaire, Buena Vista Social Club, Cesaria Evora.

Youssou N'Dour has had his moments of glory, of course. His duet with Neneh Cherry was a world-wide smash. But one of his long-time sidemen admitted to me that it was the worst thing that could have happened. The hit validated Youssou N'dour's grandiose vision of his career and he has continued to distort the musical traditions of his culture ever since in a fruitless attempt to reproduce the success of "Seven Seconds". And we can but imagine his response when Star Band's old Dakar rivals, Orchestra Baobab, reformed a few years ago with the support of World Circuit Records, spent two weeks recording live in Youssou N'Dour's studio and sold three times more copies than any recent effort of his.

What are we to make of this vignette? The assumption seems to be that pressure to impose alien standards on music rooted in a local tradition comes from the outside. In the light of my experience, I would have to say that is very rarely the case. Local cultures are under constant threat from the forces of globalization and modernity. But music is no more or less on the defensive than local cooking, crafts, clothing, agriculture or the environment. The issues presented by the desire of underdeveloped countries to achieve prosperity touches every area of life and culture, and we can hardly support the idea that economic development is in and of itself destructive of cultural heritage and must be resisted. That way lies folklorist Alan Lomax's perhaps apocryphal anger at Mississippi's rural electrification project in the 1930s. We can all, however, agree on the inherent value of musical traditions and look for ways to resist the heedless discarding of centuries-old vocal and instrumental styles. Can we not? 
Today there are an equal number of encouraging and discouraging signs. Some of the most depressing images come from Abidjan in the Cote d'Ivoire, where, as in the former Soviet bloc, the collapse of old structures has led to weak leaders playing the nationalist card. Unlike Yugoslavia, where killers sang Serbian folksongs as they marched into Srebrenica, the gangs supporting President Gbagbo have declared their hostility to all things traditional. Their garb is an homage to American gang-banging and hip-hop; their leaders express nothing but contempt for their cultural heritage, listen to nothing but rap and want nothing more than for America to invade, kill the Muslim northerners and bring the West's materialistic culture in to replace the old ways they feel have given them so little.

Abidjan is an extreme situation, but suspicion of "old-fashioned" approaches appears in many guises. When I went to Havana in 1995 to record the all-star orchestra Cubanismo, I was approached at the end of the first day's session by one of the musicians. He had enjoyed performing arrangements of the 1940s and 1950s dance tunes with 15 other players in the old Egrem studio (where a year later the Buena Vista Social Club would be recorded and filmed). But, he wanted to know, when were we going to make the "real" recording? "This is the real recording", I said. "But what about the backing tracks and the overdubs?", he wanted to know. "You aren't going to release it just like this, are you?"

To him, recording a roomful of great musicians playing pure Cuban dance music was a nice way to spend an afternoon and if some crazy producer was willing to pay for it, that was fine. But he couldn't see that producer as a serious bridge to the "commercial" world of the international music business. For that, there would have to be effects, carefully layered backing tracks, multi-tracked vocals and all the tricks he assumed was the way to international success. The recordings we made that week in Havana sold an astonishing 150,000 copies. Astonishing, that is, until it was dwarfed by the millions of Buena Vista CDs that flew off the shelves in the following years. None of the slick recordings of Cuba's own music industry or the visiting Spanish or Mexican producers have sold anything approaching those amounts. Cubans were generally bemused by Buena Vista's success; some were contemptuous - "tourist music", they called it. The music Cubans were listening to in the late 1990s was timba, a blend of breakbeats and son that has never held any appeal for the fans of Buena Vista or Cubanismo.

So where lies the distortion? Are the producers and audiences of the Developed World damaging Cuban culture by preferring Ibrahim Ferrer, Bebo Valdez and Jesus Alemany to the gold-chained glitz of Charanga Habanera and EI Medico de la Salsa? The notion that the forces of International Musical Capitalism are recklessly endangering local traditions does not square with my experience. Musicians from developing countries are certainly caught between conflicting forces. But those forces are not their fellow countrymen begging them to remain true to their roots 
while cynical World Music entrepreneurs dangle riches in exchange for selling their musical souls. The obverse - a producer from London or Paris or New York trying to convince a musician to turn off his drum machine or his synthesizer and play in the traditional fashion while the local audiences berate him for being "backward" - is closer to reality.

I went recently to a concert given by Abdel Gadir Salim in London. Salim's recordings have been championed by BBC DJ Charlie Gillett, so the audience was equally divided between World Music fans and expatriate Sudanese. For the first few bars, Salim's rich voice mesmerized everyone as he picked out sinewy riffs on the oud. Then he nodded to the band and they joined in as the rhythm picked up speed. When the keyboard player hit a button on his instrument, my friends and I looked at each other in dismay. He had triggered a cheesy drum machine, loud, overbearing and plodding. The tarambuka player was no longer providing the rhythmic spark, he was simply tapping along, following the machine. The next tune followed the same pattern. Slowly, white faces in the crowd began drifting towards the door. The Sudanese audience, on the other hand, seemed happy. They were enjoying the lyrics and the tinny beat did not appear to bother them. What was our problem?

The inescapable fact is that there are two audiences who want different things from a "World Music" performer. The World Music audience wants "authenticity", while the "authentic" audience wants their own version of excitement, which in most cases takes - at least partly - the form of "modernity". In Kartoum, the bright sound of a drum machine may seem modern and attractive. I have been to many a Bulgarian wedding and tried hard to tune out the terrible echo that the wedding orchestras love to turn up to ear-splitting level until you cannot tell a real note from one of its electronic offspring. How should a promoter in the Developed World negotiate these conflicts? Do the preferences of the artist's home audience define what is genuine?

There was a time in the early 1980s when Zairean audiences in Kinshasa, Brussels and Paris enjoyed the same soukous styles and artists as audiences at World Music festivals. The beauty of classic soukous lies in the way three fingerpicked guitars blend and play off each other, creating a texture both sexy and ethereal, with an exhilarating dance floor beat. World Music festival audiences loved it. But when the bands started adding the sustained pad of an electric keyboard, the spaces between the arpeggios were filled and the guitars did not chime and swing the way they had. More and more groups started touring with two guitars and a keyboard and the sound became far less interesting and attractive. At the same time, dancers in Paris and Kinshasa night clubs were demanding a more modern mix on recordings, and producers complied, driving a wedge between the two audiences. At one time, soukous might have battled reggae for a spot at the top table of the world's dance rhythms. But by the late 1980s, international touring by Zairean bands had almost ceased. After 15 years' exile, soukous is now back on the 
World Music agenda with a group called Kekele, a Baobab/Buena Vista-inspired outfit of aging veterans, whose delicate 1960s' style rumba goes down a treat with World Music audiences. But I doubt they get any offers to play Kinshasa.

Another point of reference for this conflict lies in the American south. The "Oh Brother Where Art Thou" soundtrack won every award a few years ago and sold millions of records. "Man of Constant Sorrow was" Record of the Year in the Country Music Association awards. But, in truth, it was about as popular with country audiences as Buena Vista was with Latin ones. Which is to say, not at all. I read in Billboard magazine that not a single track of the CD had received so much as one play on any commercial country radio station. Which matches the total airplay of Buena Vista on commercial Latin stations in the US. Buena Vista and Oh Brother are entirely NPR (National Public Radio), Middle-class phenomena, produced by "outsiders". Does this mean we should insist that the arts centres currently booking Ralph Stanley and the Clinch Mountain Boys cancel him on grounds of in-authenticity and book Travis Tritt instead?

Charges of distortion ring true when applied to the producers who want to update World Music on post-modern rather than mass market terms. Their electronic beats are of the hip variety championed by DJs in Paris, London and San Francisco rather than the mainstream version. There are also pretentious fusions like One Giant Leap where technology allows Asha Bosle to duet with Michael Stipe over a vaguely exotic mid-Atlantic beat. Or there are traditional singers recorded in the style of the Anglo-American singer-songwriter like, for example, Gigi of Ethiopia. Her producer and husband, Bill Laswell, supervised a disastrously overproduced recording, which cost a fortune and hardly sold at all. Then Network, a German label of impeccable judgement, invited her to make a traditional Ethiopian record. Laswell did his best to steer it towards arid over-production but Network kept rejecting the finished masters until they finally got what they wanted. Their Zion Roots project has been hailed by critics, Gigi has been invited to tour on several continents and the CD has been far more commercially successful than the first. I missed her appearance in London, but reports are that Laswell was very much in charge and both audiences - Ethiopians and World Music fans - left disappointed. Despite repeated object lessons such as this, large amounts of money are spent every year on this kind of distorted production. The successful records and tours, meanwhile, continue, over and over, to be those that adhere to the most virtuosic and faithful representation of a distinctive culture.

A rising star of the concert and festival circuit is the Portuguese fado artist Misia. She looks like a sexy twenty-first century bride of Frankenstein and has been marketed aggressively and skilfully. But her music - at least on the first two CDs - is pure traditional fado. She has far outsold the other post-modern Portuguese singers, most of whose names also seem to begin with "M", but whose approach was to water 
down the traditional fado rhythm with singer-songwriter, classical or pop touches. Once again, the so-called "commercial" approach has been a dead-end.

Ambitious Third World artists all have one hero: Bob Marley. The curious thing, however, is that while they revere him, they ignore the lessons his success teaches. Marley's melodies may have owed debts to American blues and gospel, or even John Lennon and Bob Dylan, but the rhythms he employed were uncompromisingly Jamaican. He never diluted reggae and as a result, reggae triumphed. There are now reggae bands singing in Polish, Malay, Apache and Zulu. Where is the parallel passion and commitment by the international stars of mbalax, mbaqanga, tarantella, or samba. So many of the records promoted - usually unsuccessfully to the World Music audience are deeply compromised rhythmically and to my ears, rhythm is where musical cultures make their home.

Just as I believe that staying true to one's own musical roots is a smart career move, I have also found that traditions and modernity can co-exist. I remember standing in a crowd in Uptown New Orleans watching a Second-Line parade one Sunday afternoon. Suddenly the music of the brass band was drowned out by bass notes booming from the giant speakers of an SUV pulling up behind me on a side street. I turned and saw a couple of guys in home-boy overalls, bandanas and gold chains turn off the music and get out holding a saxophone and a trombone. They gave the mouthpieces a lick and ran off to join the band.

On another occasion, I accompanied the Brazilian singer Caetano Veloso on a visit to Projecto Axé, a charity he sponsors in Salvador de Bahia. Many of the kids who live in the charity's home had been sleeping rough and sniffing glue only months before. At Axé, they learn to read, study a trade and help make the clothes they wear and the costumes the organization supplies for Carnival. Everything at Axé is tied to the Afro-Brazilian tradition. Like most kids, they love all things shiny and modern, but they are devoted to the music of the blocos as well and form their own samba percussion groups. For them, there is no conflict, and I had the strong feeling that the amazing successes Axé achieves would be impossible without the cultural pride at the heart of its every activity.

New Orleans and Salvador are exceptional places. It would be hard to find similar anecdotes in LA or London. But over the years, I have noticed an interesting pattern. After Franco's death, for example, Spain indulged in every modern vice denied to them for so many years. Pornography dominated the newsstands while heavy metal and disco clogged the airwaves. Visitors who asked about flamenco were viewed as hopelessly square, deserving of nothing better than the cheesy tourist tablaos. But in the 30 years since, a shift has taken place. Spaniards began paying attention to what the rest of the world told them was a great art form, to be as treasured as the canvases of Valasquez or the poems of Lorca. Now flamenco 
sits comfortably at the head table in Spain. There remain plenty of heavy metal as well as flamenco fusions of dubious quality. But real, unadulterated flamenco has regained its place at the heart of Spanish culture. And this same cycle of rejection and recovery has been repeated in culture after culture around the world.

In the summer of 2005, I was in Bulgaria for the Koprivshtitsa Festival, which takes place in a small village high in the Balkan mountains once every five years. It brings together amateur village musicians from every region of the country. For three days, across seven stages, singers, dancers and instrumentalists have their ten minutes of fame and those selected by the judges perform on nationally televised highlight concerts. Thousands of listeners and performers camp out in army tents, singing, dancing and partying every night under the stars after the official concerts have ended.

Or at least that is the way it was when I first attended, twenty years ago. The latest festival was marred by torrential country-wide floods that forced a curtailment of the schedule and drove many of the villagers to leave early, worried about their farms, livestock and property. But even allowing for the storms, it was clear things had changed radically. Twenty years ago, evenings in the town were filled with the sound of singing and the wail of the gaida. Chains of horo dancers wove in and out of bars and restaurants and formed huge spirals in clearings in the tent cities. Professional musicians from the State and regional ensembles came to jam with the amateurs, hang out and learn some new licks or melodies.

In 2005, walking through the town one was assaulted by the deafening sound of folk music blasted through sound systems at the stalls selling CDs of both acoustic music and the electronic pop-folk that dominates the Bulgarian charts and television. There were tents set up along the river selling beer and kebabs, with wedding bands performing with drum kits and huge p.a. systems in a style that was a hybrid of Macedonian and Serbian music and the Thracian wedding music first championed by Ivo Papasov (a musician I helped bring to audiences outside Bulgaria in the late 1980s). At the time, the more traditional Bulgarian musicians and singers I worked with were shocked that I would record Ivo, whom they saw as leading a perversion of the national traditions that had been proudly kept alive for so many years. It seemed to me that both styles were great and there need be no conflict.

But one night in Koprivshtitsa 2005 was sobering. There might have been traditional groups ready to play for dancing, but the sheer volume of amplified sound emanating from the booths and the tents made it impossible to imagine how they would ever be heard by a circle of dancers. And it was not just the volume; the wedding-band music has evolved, bringing in insistent oriental beats from Turkey and Egypt as well as some of the pounding simplicity of Serbian turbo-folk, making it seductively easy to dance to as well as ear-splittingly loud. There was a great 
moment late in the evening, however, when a pair of zorna players and a couple of teppanitsas led a huge horo down the main street, the piercing wail of the ancient double-reed instruments and the drums sending the stall-holders running for cover.

Earlier in the same week I had been to a few gypsy weddings and found to my delight that the obsession with echo has gone - everyone can now hear the singer or horn player's embellishments without wondering which are the new notes and which are repeats of earlier ones. There were plenty of young musicians in both the wedding bands and the traditional groups on show at Koprivshtitsa, so there is plenty of hope for the future. But it is clear that Bulgaria, once an exemplary outpost of pride in its music legacy, is changing just as the rest of the world is changing. The subtleties of traditional music-making are becoming as hard to find as traditional weaving or cheese-making.

I wondered if middle-class Bulgarian kids were starting to take an interest in their own musical heritage. The answer came in the form of some CDs given to me in the hope that I could put them in touch with festivals and producers in England, France or America. But the CDs were disappointingly predictable fusion, newagey confections with none of the appeal of Papasov's band, or of the best of the traditional music of this culturally rich land. The new groups say they have trouble getting booked outside the Balkans and think it is because they lack connections. When I tried to talk to them as I talked to Youssou N'dour 20 years ago, I got blank, uncomprehending looks.

This dichotomy appears over and over in all areas of modern life. The Chinese authorities have knocked down miles and miles of traditional wooden housing in Beijing and Shanghai and replaced it with modern apartment towers and shopping malls. They are finally getting the idea that foreign tourists will have no interest in visiting cities that resemble the soulless urban centres back home and have started preserving old neighbourhoods and even re-building bulldozed traditional housing using old blueprints.

Is it too pat to suggest that the global World Music audience, with its love of tradition as a refuge from a menacing and unattractive modern world, has a function here? To use its economic power to pay for the preservation of traditional art forms from all manner of cultures until the home base turns around and says "we are so glad we did not throw this all away before we realized how great it was". I hear that the bars of Buenos Aires are converting from modernized and electrified music and traditional tango is all once again all the rage, just as the Argentine Finance Ministry has rejected the strictures of the IMF and the American banks and embraced locallymade goods and a local idea of an economic future. More and more economists and social scientists are starting to embrace localism as a way forward, now that the pitfalls and shortcomings of globalization have been exposed. I do not think 
it is wrong to point out to musicians the strength of their musical heritage and to suggest that they might have a better export market by sticking with what makes them unique. Perhaps one day dance clubs in Central Africa will chime again to the brilliant sound of three guitars and no keyboards. And maybe Youssou N'Dour will make the great mbalax record the world - including Dakar - is waiting for. 